\title{
KARAKTERISTIK KEAGENAN BANK
}

\author{
Andika Persada Putera \\ aputera@permatabank.co.id \\ Kepala Bidang Hukum Bank Permata Cabang Darmo Surabaya
}

\begin{abstract}
Rapid development of the national economy and banking external environment, such as nonbankfinancial institutions, capital markets, securities companies, insurance as well as the needs of the people, are causing the services and banking products also developed and varied. Banking activities not only engage in activities that are primary (core business), but also non-core business such as agency activities as Mutual Fund Sales Agent (APERD) and bancassurance. The implementation of bank agency, when the transaction is done and the position of non-bank products principals is represented by the bank as a sales agent, the principal responsibility for third-party funds invested in investment products belongs to the principal. However, all forms of relations and communications between the principal with a third party at a bank as an agent or intermediary for both parties.
\end{abstract}

Keywords: bank, bank agency, investment.

\begin{abstract}
Abstrak
Seiring pesatnya perkembangan perekonomian nasional serta lingkungan eksternal perbankan, seperti lembaga keuangan bukan bank, pasar modal, perusahaan sekuritas, asuransi serta kebutuhan masyarakat, menyebabkan jasa-jasa dan produk-produk perbankan turut berkembang dan bervariasi. Kegiatan perbankan tidak hanya melakukan kegiatan yang bersifat utama (core business), tetapi juga bersifat non core business seperti kegiatan keagenan sebagai Agen Penjual Reksa Dana (APERD) dan bancassurance. Adapun pelaksanaan keagenan bank, ketika dilakukan transaksi produk non bank sekalipun kedudukan prinsipal diwakili bank sebagai agen penjual, prinsipal bertanggung jawab terhadap dana pihak ketiga yang diinvestasikan pada produk investasi milik prinsipal tersebut. Namun, segala bentuk hubungan dan komunikasi antara prinsipal dengan pihak ketiga dilakukan melalui bank sebagai agen atau perantara kedua pihak
\end{abstract}

Kata Kunci: bank, keagenan bank, investasi. 


\section{Pendahuluan}

Pada dasarnya bank adalah badan usaha yang menjalankan kegiatan penghimpunan dana dan menyalurkannya kembali kepada masyarakat dalam bentuk pemberian kredit sekaligus pemberian jasa-jasa perbankan dalam lalu lintas pembayaran dan lainnya. Sesuai penjelasan Shelagh Heffernan bahwa:

Banks are normally distinguished from other types of financial firms in that they provide deposit and loan product. The deposit product pay out money on demand, or after some notice. Thus, banks are in the business of managing liabilities, and, in the process, banks also lend money, thereby creating bank assets. Alternatively, one can argue banks are in the business of managing assets, which are funded by deposits or other liabilities. As it demonstrated in the next section, the intermediation function normally result in banks offering a payments service to their customers. ${ }^{1}$

Dengan demikian, bank berfungsi sebagai lembaga intermediasi sesuai Pasal 3 Undang-Undang Republik Indonesia Nomor 7 Tahun 1992 sebagaimana telah diubah dengan Undang-Undang Nomor 10 Tahun 1998 Tentang Perubahan Undang-Undang Nomor 7 Tahun 1992 Tentang Perbankan² bahwa fungsi utama perbankan Indonesia sebagai penghimpun dan penyalur dana masyarakat. Dua fungsi ini sebagai bisnis utama bank (core business bank), ibarat dua sisi mata uang yang menjadi satu kesatuan.

Menurut Shelagh Heffernan ada dua jawaban mengapa bank sebagai lembaga intermediasi: First, the presence of informations costs undermines the ability of a potential lender to find the most appropriate borrower, in the absence of intermediation. Second, borrowers and lenders have different liquidity preferences. ${ }^{3}$

Sebagai badan usaha, bank juga berorientasi bisnis mencari keuntungan selain dengan melakukan fungsi intermediasi juga melalui jasa pelayanan (services) guna mendukung fungsi intermediasi tersebut, melayani transaksi keuangan dan lalu lintas pembayaran sehingga disebut agent of services. Jadi berkaitan dengan fungsi agent of services, setiap industri maupun individu tidak lepas dari kebutuhan pelayanan bank. Oleh karena itu, bank selalu dituntut meningkatkan mutu pelayanan pada masyarakat dalam bentuk inovasi berbagai produk dan pelayanan.

Berkaitan pula dengan pesatnya perkembangan perekonomian nasional serta lingkungan eksternal perbankan, seperti lembaga keuangan bukan bank, pasar modal, perusahaan sekuritas, asuransi serta kebutuhan masyarakat, menyebabkan jasa-jasa dan produk-produk perbankan turut berkembang dan bervariasi. Kegiatan perbankan tidak hanya melakukan kegiatan yang bersifat utama (core business), tetapi juga bersifat non core business seperti kegiatan keagenan sebagai Agen Penjual Reksa Dana (APERD) dan bancassurance.

Shelagh Heffernan, Modern Banking in Theory and Practice, England: John Wiley \& Sons, 1996, h. 15.

Undang-Undang Republik Indonesia Nomor 7 Tahun 1992 sebagaimana telah diubah dengan UndangUndang Nomor 10 Tahun 1998 Tentang Perubahan Undang-Undang Nomor 7 Tahun 1992 Tentang Perbankan (Lembaran Negara Republik Indonesia Tahun 1998 Nomor 182. Tambahan Lembaran Negara Republik Indonesia Nomor 3790). Selanjutnya disebut UU Perbankan.

3 Shelagh Heffernan, Op.Cit, h. 18. 
Kedua produk tersebut merupakan produk investasi yang diterbitkan oleh lembaga keuangan bukan bank sehingga bukan sebagai produk bank disebut produk non bank. ${ }^{4}$ Produk non bank merupakan produk hybrid, yaitu perpaduan antara produk perbankan, asuransi atau pasar modal dan di Indonesia masih merupakan produk asuransi atau pasar modal murni sehingga bank hanya berfungsi sebagai penjual (agent) dan mendapatkan komisi (fee) dari jasanya tersebut. Jadi keuntungan bank menjual produk hybrid selain menerima komisi sekaligus dapat memperbesar customer base dan menjaga loyalitas nasabah. ${ }^{5}$

Dari sudut perbankan terdapat dua sistem yang berlaku, yaitu commercial banking berlaku di Indonesia dan Amerika Serikat yang melarang bank melakukan kegiatan usaha keuangan non bank seperti asuransi, dan universal banking yang dianut antara lain negara-negara Eropa dan Jepang yang membolehkan bank melakukan kegiatan usaha keuangan non bank seperti investment banking dan asuransi. ${ }^{6}$ Dalam konsep sistem universal banking sebagian besar atau seluruh jasa-jasa keuangan dilakukan dalam satu struktur perbankan tunggal, yang meliputi: intermediation, trading of financial instruments, foreign exchanges and their derivaties; brokerage; corporate advisory services, including mergers and acquisitions services. ${ }^{7}$ Jadi latar belakang munculnya fenomena bank sebagai APERD adalah adanya desakan untuk menggeser fungsi bank yang saat ini sebagai intermediasi murni menjadi universal banking, sekalipun perlu kajian mendalam khususnya untuk mengubah dan menetapkan regulasi yang tepat. ${ }^{8}$ Adanya produk hybrid ini menandakan sistem perbankan Indonesia perlahan akan ditarik ke dalam universal banking.

Dari sisi masyarakat, terjadi perubahan paradigma dan wawasan berpikir yang semakin kritis guna menunjang terjadinya peningkatan kebutuhan hidup sehingga perlu perencanaan keuangan yang lebih baik. Apabila sebelumnya secara konservatif menyimpan dana di bank dalam bentuk simpanan tabungan ataupun deposito yang sifat pendapatannya tetap, lambat laun beralih ke produk investasi untuk mendapatkan keuntungan lebih tinggi dibanding simpanan bank. Dalam praktek terdapat sejumlah dana nasabah bank yang beralih ke produk investasi. Guna menjaga agar nasabah tidak pindah ke bank lain, selain berinovasi produk salah satunya bank bekerjasama dengan perusahaan sekuritas ${ }^{9}$ menjadi APERD, mendapat respon positif

4 Istilah "produk non bank" tidak ditemukan definisi formal namun dalam praktek perbankan diartikan sebagai kebalikan / a contrario dari istilah "produk bank" yang tercantum dalam Peraturan Bank Indonesia Nomor 7/6/PBI/2005, tanggal 20 Januari 2005, Surat Edaran Bank Indonesia Nomor 7/25/DPNP, tanggal 18 Juli 2005 dan Surat Edaran Bank Indonesia Nomor 11/35/DPNP, tanggal 31 Desember 2009. Dengan demikian, istilah produk non bank dapat diartikan dan didefinisikan sebagai produk dan atau instrumen keuangan yang tidak diterbitkan oleh bank, namun diciptakan, diterbitkan dan atau dikembangkan oleh lembaga keuangan bukan bank.

5 Zurkarnain Sitompul, "Menyambut Kehadiran Otoritas Jasa Keuangan (OJK)", Pilars No.02/Th.VII/12, 8 Januari 2004, h. 3.

$6 \quad$ Ibid, h. 2-3.

7 Dian Ediana Rae, Transaksi Derivatif dan Masalah Regulasi Ekonomi di Indonesia, Jakarta: Elex Media Kompotindo, 2008, h. 235.

8 Try Widiyono, Aspek Hukum Operasional Transaksi Produk Perbankan di Indonesia, Bogor: Ghalia Indonesia, 2006, h. 1.

9 Dimaksud Perusahaan Sekuritas adalah suatu perseroan terbatas yang menjalankan kegiatan usahanya sebagai Manajer Investasi dan telah memperoleh ijin dari Badan Pengawas Pasar Modal-Lembaga Keuangan 
nasabah karena Reksa Dana terdiversifikasi dan dikelola oleh Manajer Investasi mengurangi tingkat risiko kerugian, selain dana investasi yang sesuai dengan kondisi keuangan nasabah. Kegiatan bank sebagai APERD berdasarkan pada ketentuan, yaitu :

1. UU Perbankan, Pasal 6 huruf $n$, yaitu melakukan kegiatan lain yang lazim dilakukan oleh bank sepanjang tidak bertentangan dengan undang-undang ini dan peraturan perundang-undangan yang berlaku.

2. SEBI Nomor 5/13DPG/DPNP, tanggal 3 Oktober 2003, menyebutkan bank sebagai agen penjual Reksa Dana, dalam melakukan kegiatan tersebut prinsipnya harus mengacu pada ketentuan yang berlaku yang mencakup namun tidak terbatas pada UU Perbankan, UU Pasar Modal dan ketentuan Bapepam, ketentuan BI tentang Penerapan Manjemen Risiko Bagi Bank Umum, Transparansi Kondisi Keuangan Bank, Penerapan Prinsip Mengenal Nasabah dan memperhatikan Pernyataan Standar Akuntasi Keuangan.

3. PBI Nomor 7/6/PBI/2005, tanggal 20 Januari 2005, Bab I ketentuan umum, Pasal 1 , angka 4 , menyebutkan yang dimaksud produk bank adalah produk dan atau jasa perbankan termasuk produk dan atau jasa lembaga keuangan bukan bank yang dipasarkan oleh bank sebagai agen pemasaran.

4. SEBI Nomor 7/19/DPNP, tanggal 14 Juni 2005 juncto SEBI Nomor 11/ 36 /DPNP, tanggal 31 Desember 2009, perihal penerapan manajemen risiko pada bank yang melakukan aktivitas berkaitan dengan Reksa Dana.

5. SEBI Nomor 7/25/DPNP, tanggal 18 Juli 2005, menyebutkan yang dimaksud jenis produk bank, yaitu pengelompokan produk dan atau jasa yang diterbitkan bank sesuai dengan ketentuan yang berlaku, seperti tabungan, deposito, kredit/pembiayaan, dan produk dan atau jasa lembaga keuangan lain yang dipasarkan bank seperti Reksa Dana dan Bancassurance.

6. SEBI Nomor 11/35/DPNP, tanggal 31 Desember 2009, menyebutkan bahwa "Aktivitas Bank adalah jasa yang disediakan oleh Bank kepada nasabah, antara lain adalah jasa keagenan dan/atau kustodian."

7. Keputusan Ketua Badan Pengawas Pasar Modal Dan Lembaga Keuangan Nomor KEP-10/BL/2006 tanggal 30 Agustus 2006, tentang Pendaftaran Agen Penjual Efek Reksa Dana.

8. Keputusan Ketua Badan Pengawas Pasar Modal Dan Lembaga Keuangan Nomor KEP-11/BL/2006 tanggal 30 Agustus 2006, tentang Perilaku Agen Penjual Efek Reksa Dana.

Dampak positif penjualan Reksa Dana melalui bank bagi pihak eksternal maupun internal bank sebagai bentuk simbiosis mutualisme. Bagi eksternal bank keterbatasan MI hanya di kota besar serta tidak mampu membuka cabang di berbagai kota guna memasarkan produk investasinya, sedangkan bank punya banyak cabang di berbagai kota. Dengan jaringan kantornya sebagai ujung tombak, bank dapat menjaring investor sebanyak mungkin dan memberi akses masyarakat luas untuk berinvestasi jangka panjang. Masyarakat kota kecil yang memiliki dana besar dapat membeli Reksa Dana melalui kantor bank di kotanya, merupakan suatu yang mustahil dapat dilakukan oleh Manajer Investasi mengingat keterbatasan infrastruktur jaringan pelayanannya. Oleh karena itu, Manajer Investasi bekerja sama dengan bank sebagai 
APERD, agar Manajer Investasi lebih produktif, efektif dan efisien untuk mencapai target bisnis dalam mengakumulasi dana jangka panjang tersebut. Sedangkan, bagi internal bank. dapat mempertahankan existing nasabahnya (cross selling), mencegah pindah ke bank lain, meningkatkan customer base dan fee based income dari biaya pembelian (subscription fee), biaya penjualan kembali (redemption fee) dan komisi dari Manajer Investasi. Bila bank sebagai investor, membuka peluang memperbaiki kinerja neraca serta struktur pendanaannya dengan mengalihkan deposito yang biaya dana (cost of fund) relatif tinggi ke Reksa Dana agar keuntungan dalam bentuk interest margin semakin baik.

Pada kondisi di perbankan saat ini, pendapatan non-bunga (fee based income) merupakan salah satu fokus bank sebagai potensi mendapatkan revenue selain dari bunga kredit guna menutupi biaya operasional bank yang semakin meningkat. Seperti yang dikatakan bahwa fee based income merupakan pendapatan non bunga yang diperoleh dari usaha bank selain dari pemberian kredit. ${ }^{10} \mathrm{Hal}$ ini lebih banyak berupa biaya jasa yang diperoleh bank karena kegiatan operasionalnya, seperti dari jasa transfer/ LLG/ RTGS, jasa inkaso, jasa dari pembayaran telpon, listrik, air PDAM. Biaya administrasi yang diperoleh bank dari tabungan nasabahnya, pendapatan atas silisih kurs jual beli valuta asing ataupun fee dari transaksi letter of credit (L/C). Selain itu, juga bisa berasal dari biaya yang diperoleh dari pemakaian ATM bersama oleh berbagai bank serta annual fee dari kartu kredit."

Kegiatan bank ini berdampak positif bagi perkembangan Reksa Dana yang diwujudkan dalam bentuk kerja sama (mutual agreement) bank sebagai APERD dan Manajer Investasi sebagai pengelola dana. Dari data total dana kelolaan (asset under manajement/AUM) Reksa Dana sepanjang 2012 dan 2013 sebagai berikut: ${ }^{12}$

Tabel 1. Data Kelolaan Reksa Dana

\begin{tabular}{|c|c|c|}
\hline \multicolumn{3}{|c|}{ DATA KELOLAAN REKSA DANA } \\
\hline Data & 2012 & 2013 \\
\hline Reksa Dana & Rp 182,7 triliun & Rp 185,4 triliun \\
\hline Unit Penyertaan & 113,2 miliar & 120,3 miliar \\
\hline \multicolumn{2}{|c|}{ DATA MAYORITAS KONTRIBUSI } & JUMLAH \\
\hline \multicolumn{2}{|c|}{ Reksa Dana Saham } & Rp 79,38 triliun \\
\hline \multicolumn{2}{|c|}{ Reksa Dana Terproteksi } & Rp 38,19 triliun \\
\hline \multicolumn{2}{|c|}{ Reksa Dana Pendapatan Tetap } & Rp 34,95 triliun \\
\hline \multicolumn{2}{|c|}{ Reksa Dana Campuran } & Rp 27,66 triliun \\
\hline \multicolumn{2}{|c|}{ Reksa Dana Pasar Uang } & $\mathrm{Rp} 11,23$ triliun \\
\hline \multicolumn{2}{|c|}{ Reksa Dana Indeks } & Rp 395,95 miliar \\
\hline
\end{tabular}

Kondisi tersebut ditunjang oleh: ${ }^{13}$

Rp 182,7 triliun

113,2 miliar

10 Andika Persada Putera, 'Fee Based Income' sebagai Alternatif Pendapatan Bank, Surabaya Post, 12 Januari 2006, h. 4.

11 Ibid.

12 Sindonews.com, http://ekbis.sindonews.com/read/2014/01/07/32/824281/dana-kelolaan-reksa-dana2013-naik-tipis, diunduh 28 Maret 2014.

13 diunduh 21 April 2014. 
Tabel 2. Data Pihak Berkaitan Dengan Reksa Dana

\begin{tabular}{cc}
\hline DATA BERKAITAN REKSADANA & JUMLAH \\
\hline Reksa Dana Aktif & 898 \\
Manajer Investasi & 74 \\
Bank APERD & 23 \\
Bank Kustodian & 16 \\
\hline sumber $\cdot$ http://aria bapepam go.id
\end{tabular}

sumber : http://aria.bapepam.go.id,

\section{Timbulnya Lembaga Perantara}

Pesatnya perkembangan perekonomian dewasa ini menyebabkan terjadi perubahan mekanisme dalam praktek transaksi bisnis komersial, terutama konsep pemasaran dan penjualan suatu produk. Secara konvensional, pemasaran dan penjualan suatu produk perusahaan dilakukan sendiri oleh perusahaan. Dalam perkembangannya dapat dilakukan pihak lain sebagai perantara dengan konsep interaksi dan sinergi dalam bentuk kerjasama untuk meningkatkan daya guna dan produktivitas sumber daya masing-masing guna mencapai hasil maksimal dibandingkan tanpa konsep kerjasama. Selain itu, agar produk dapat segera beredar dan tersebar ke seluruh masyarakat di berbagai tempat untuk mempercepat proses pemasaran dan distribusinya.

Ridwan Khairandy mengatakan bahwa untuk memasarkan dan menjual produk industri baik berupa barang atau jasa kepada konsumen, pelaku usaha atau produsen memiliki dua pilihan, yaitu memasarkan dan menjual sendiri produk tersebut atau dilakukan oleh agen atau distributor yang ditunjuk. Dalam hukum kontrak atau hukum bisnis dikenal dengan perjanjian keagenan (agency agreement) dan perjanjian distribusi (distributorship agreement). ${ }^{14}$

Jadi adanya kebutuhan pada suatu perusahaan sebagai perantara untuk memperluas jaringan pemasaran barang dan jasa menimbulkan perusahaan keagenan di Indonesia. "Demi alasan efisiensi, maka produser tidak menjual barang dan jasa langsung kepada konsumen, tetapi menjualnya melalui pedagang perantara atau middle man seperti agen, distributor." ${ }^{15}$ Kondisi ini banyak terjadi juga dalam bisnis internasional, produsen luar negeri menunjuk agen pemasaran produknya di dalam negeri karena lebih menguntungkan dan praktis dari pada membuka cabang sendiri. Demikian halnya dengan pemasaran dan penjualan produk non bank sebagai produk investasi di pasar modal dan produk asuransi, kini dipasarkan dan dijual oleh lembaga perbankan yang notabene juga mempunyai produk sendiri, dalam konsep kerjasama sebagai agen pemasaran dan penjual produk tersebut.

Kondisi ini terjadi selain karena tuntutan bisnis yang membutuhkan suatu perantara guna memperluas jaringan pemasaran dan penjualan produk suatu perusahaan agar lebih efektif, efisiensi dan menguntungkan pemilik produk dari pada menjualnya langsung kepada konsumen, juga untuk meningkatkan kinerja perusahaan, keuntungan perusahaan tanpa investasi mahal dengan membuka cabang baru dan penambahan karyawan di wilayah pemasarannya. Bagi bank, yang paling utama untuk meningkatkan fee based income atau keuntungan dengan memanfaatkan tersebarnya cabang bank diberbagai wilayah di Indonesia. Dengan demikian,

14 Ridwan Khairandy, Pokok-Pokok Hukum Dagang Indonesia, Yogyakarta: FH UII Press, 2013, h. 247.

15 Suharnoko, Hukum Perjanjian Teori dan Analisa Kasus, Jakarta: Kencana Prenada Media, 2012, h. 39. 
konsep keagenan bank ini telah berjalan pesat seiring dengan kebutuhan atas perkembangan bisnis tersebut.

Bank sebagai agen pemasaran dan penjual produk non bank pada dasarnya hanya sebagai perantara antara prinsipal sebagai pemilik produk dengan pihak ketiga sebagai pembeli. Bank sebagai pihak tengah yang menjembatani kebutuhan prinsipal dengan pihak ketiga terhadap produk non bank karena keterbatasan kondisi prinsipal. Dalam hal ini bank bertindak selaku kuasa atau wakil prinsipal dalam berhubungan dengan pihak ketiga berkaitan dengan transaksi produk non bank tersebut.

Menurut David Kelly, agen (agent) adalah seseorang yang diberikan kewenangan oleh prinsipal (principal) untuk mewakili dirinya melakukan suatu perbuatan hukum atau hubungan hukum dengan pihak ketiga. ${ }^{16}$ Hubungan hukum yang terjadi antara bank dengan prinsipal berdasarkan kontrak keagenan berupa kontrak kerjasama yang dibuat para pihak, yang mengatur hak dan kewajiban para pihak. Bank wajib menjalankan kewajiban dalam kontrak dan tidak boleh melakukan tindakan diluar kontrak. Artinya, apabila bank melakukan tindakan sesuai kontrak, segala risiko menjadi tanggung jawab prinsipal, sedangkan apabila diluar kontrak menjadi tanggung jawab pribadi. Sebagaimana dikatakan Suchitthra Vasu, ${ }^{17}$ bahwa prinsipal mendelegasikan kewenangannya kepada agen dalam membuat kontrak dengan pihak ketiga dan terikat atas segala kontrak yang dibuat agen dengan pihak ketiga. Agen tidak memiliki tanggung jawab atau kewajiban berdasarkan kontrak dengan pihak ketiga.

Demikian halnya dalam pelaksanaan keagenan bank, saat terjadi transaksi produk non bank sekalipun kedudukan prinsipal diwakili bank sebagai agen penjual, prinsipal bertanggung jawab terhadap dana pihak ketiga yang diinvestasikan pada produk investasi milik prinsipal tersebut. Namun segala bentuk hubungan dan komunikasi antara prinsipal dengan pihak ketiga dilakukan melalui bank sebagai agen atau perantara kedua pihak.

\section{Karakteristik Lembaga Perantara}

Dalam bisnis komersial, lembaga perantara dimaknai sebagai penghubung antara prinsipal/pengusaha/produsen/pemilik produk dengan pihak ketiga berkaitan transaksi bisnis tersebut. Dalam kondisi tertentu, ada perantara yang melakukan tugasnya sebagai pemberi jasa yang sifatnya tidak tetap dan tidak terikat terus-menerus dengan perusahaan, hanya untuk jangka waktu tertentu saja, namun ada juga yang sifatnya tetap sebagai pekerja dalam suatu perusahaan sehingga terikat dengan kontrak kerja dengan perusahaaan. Sehubungan dengan itu, perantara dapat dibedakan menjadi dua jenis, yaitu perantara di dalam perusahaan dan perantara di luar perusahaan, ${ }^{18}$ yaitu: 1) Perantara di dalam perusahaan; dan 2) Perantara di luar

16 Ridwan Khairandy, Op.Cit., h. 247, dikutib dari David Kelly, et.al, Business Law, London: Cavendish Publishing, Limited, 2002, h. 283.

17 Ibid, h. 252, dikutip dari Suchitthra Vasu, Contract Law For Business People, Singapore: RankBook, 2001, h. 82 .

18 H.M.N. Purwosutjipto, Pengertian Pokok Hukum Dagang Indonesia (Pengetahuan Dasar Hukum Dagang), Jakarta: Djambatan, 1985, h. 43-45, menyebutkan dengan istilah pembantu-pembantu didalam dan diluar perusahaan. Dalam konteks ini, penulis lebih cenderung menggunakan istilah "perantara" perusahaan dari 
perusahaan. Pada jenis perantara di dalam perusahaan hubungan hukum timbul berdasarkan perjanjian perburuhan yang diatur dalam Pasal 1601 BW, yaitu para pekerja atau karyawan suatu perusahaan seperti pelayan toko, kasir, manajer, pimpinan perusahaan, sales/marketing, dan lain sebagainya.

Kedudukan prinsipal lebih tinggi dari perantara karena merupakan majikan sebagai pemberi perintah sedangkan perantara sebagai pekerja, karyawan atau buruh yang diperintah sehingga hubungannya bersifat tetap dan subordinasi. Sedangkan pada jenis perantara di luar perusahaan. Hubungan hukum timbul berdasarkan perjanjian dan pemberian kuasa yang diatur dalam Pasal 1792-1819 BW, seperti makelar, komisioner, ekspeditur (tiga perantara tersebut diatur dalam WvK/ Wetboek van Koophandel Indonesia), agen perusahaan, notaris, pengacara dan lain-lain. ${ }^{19}$ Kedudukan prinsipal sejajar dengan perantara yang bertindak atas nama prinsipal sehingga sifatnya tidak permanen. Definisi pemberian kuasa dalam Pasal 1792 BW menyebutkan bahwa pemberian kuasa adalah suatu perjanjian seseorang memberikan kuasanya kepada orang lain yang menerimanya untuk atas nama pemberi kuasa menyelenggarakan suatu kuasa. Dalam Pasal 1795 BW mengatur pemberian kuasa bersifat khusus yang hanya mengenai satu kepentingan tertentu atau lebih dan bersifat umum yang meliputi segala kepentingan si pemberi kuasa. Dalam Pasal 1794 BW mengatur pemberian kuasa terjadi dengan cuma-cuma kecuali diperjanjikan sebaliknya. Jika upah tidak ditentukan dengan tegas, tidak boleh lebih dari yang ditentukan Pasal 411 BW.

Dalam perkembangannya, lembaga perbankan dapat dikatagorikan sebagai perantara diluar perusahaan karena mewakilli perusahaan/pengusaha/prinsipal dalam melakukan transaksi pembayaran (payment) atau penerimaan dana dari pihak ketiga serta penyimpan dana tersebut dalam bentuk giro, tabungan ataupun deposito sesuai perintah pengusaha/prinsipal selaku nasabah bank. Dalam hal ini bank sebagai perantara bertindak dalam kapasitasnya sebagai badan usaha yang mempunyai kegiatan usaha dalam lalu lintas pembayaran yang menunjang kebutuhan transaksi perbankan pengusaha/prinsipal sebagai agent of services.

Dalam praktek terdapat beberapa istilah perantara yang mempunyai pengertian sepadan, yaitu agen, distributor, dealer, broker, representatif (perwakilan), ekspeditur, makelar dan komisioner. Perantara dalam bisnis real estate atau property, dikenal dengan istilah broker

pada "pembantu" perusahaan karena maknanya lebih dari sekedar membantu perusahaan tapi juga mewakili perusahaan sebagai penghubung antara perusahaan dengan pihak ketiga, terlepas perantara itu sebagai karyawan/ pekerja ataupun kuasa perusahaan tersebut. Periksa juga Sentosa Sembiring, Hukum Dagang-Revisi, Bandung: Citra Aditya Bakti, 2008, h. 118, yang menyebutkan secara umum, pedagang perantara dapat dibagi dalam dua golongan, yakni: 1) Berdasarkan hubungan kerja, artinya pedagang perantara dalam menjalankan tugasnya terikat perjanjian kerja antara majikan dengan pekerja, seperti: pekerja keliling, pengurus filial, pemegang prokurasi, pimpinan perusahaan; 2) Berdiri sendiri, artinya pedagang perantara tidak terikat dengan pemberi kerja, seperti: agen perdagangan/perniagaan (commercial agent), makelar (broker), komisioner (factor), perantara pedagang efek.

19 Periksa C.S.T.Kansil dan Christine S.T. Kansil, Pokok-Pokok Pengetahuan Hukum Dagang Indonesia, Jakarta: Sinar Grafika, 2008, h. 44, menyebutkan bahwa perantara yang bekerja diluar lingkungan perusahaan, seperti : agen perniagaan (commercial agent), makelar (broker), komisioner (factor), pengusaha bank. 
atau agen, dalam pasar modal terkait transaksi jual beli saham dikenal dengan istilah pialang, ${ }^{20}$ broker atau dealer, sedangkan dalam bisnis pengangkutan dikenal dengan istilah ekspeditur. Untuk istilah distributor, lebih banyak digunakan pada bisnis yang bersifat jual beli barang perdagangan atau suatu produk, sedangkan istilah agen sifatnya lebih luas dan berkarakteristik umum yang dapat menyangkut berbagai kegiatan bisnis. Mengenai agen/keagenan ini Ridwan Khairandy mengatakan di dalam praktek perdagangan, keagenan biasa digunakan oleh pabrikan (manufacturers) atau perusahaan yang memerlukan agen untuk membantu mereka dalam memasarkan atau menjual barang atau jasa kepada konsumen. Dalam konteks ini antara lain dikenal adanya agen perumahan (real estate agents), agen asuransi (insurance agents), agen perjalanan (travel agents). Agen dalam hal ini adalah agen resmi (authorized agents) dalam arti agen bertindak atas dasar kewenangan yang secara eksplisit atau tegas diberikan oleh prinsipal. Dengan perkataan lain, agen secara tegas diberikan kewenangan untuk bertindak atas nama prinsipal oleh prinsipal. ${ }^{21}$

Selain itu dikenal juga istilah representatif atau kantor representatif (representative office) yang merupakan kantor perwakilan suatu perusahaan di wilayah tertentu, bukan pihak diluar prinsipal melainkan pihak prinsipal sendiri diluar kantor pusatnya, merupakan perwakilan atau kepanjangan tangan prinsipal yang berada di wilayah tertentu dan lebih banyak bertugas dalam pemasaran produk saja. Untuk istilah makelar dalam praktek dikenal juga dengan istilah broker, calo, pialang ataupun agen tergantung sifat bisnisnya dan umumnya sebagai perantara dalam jual beli barang atau jasa. Istilah komisioner jarang dijumpai dalam pembicaraan berkaitan bisnis komersial.

\section{Agen/Agen Perniagaan (Commercial Agent).}

Istilah agen dari bahasa Inggris, agent yang berarti : agen, wakil, perantara. ${ }^{22}$ Dalam Black Law Dictionary, istilah agent diartikan sebagai "One who is authorized to act for or in place of another, a representative”. ${ }^{23}$ Menurut H.M.N. Purwosutjipto, agen perusahaan adalah orang yang melayani beberapa pengusaha sebagai perantara dengan pihak ketiga, mempunyai hubungan tetap dengan pengusaha dan mewakilinya mengadakan dan melaksanakan perjanjian dengan pihak ketiga, bukan merupakan hubungan perburuhan seperti majikan dan buruh karena tidak bersifat subordinasi, tetapi sama tinggi sama rendah. Agen perusahaan merupakan wakil pengusaha sehingga ada hubungan pemberian kuasa. ${ }^{24}$

20 Sawidji Widoatmodjo, Cara Sehat Investasi di Pasar Modal, Pengantar Menjadi Investor Profesional, Jakarta: Elex Media Komputindo, 2006, h. 22, menyebutkan bahwa salah satu ciri yang membedakan antara perdagangan di pasar modal dan perdagangan di pasar barang adalah penggunaan pialang atau broker, dalam bahasa sehari-hari disebut sebagai makelar. Jadi pada perdagangan di pasar modal pialang mutlak diperlukan.

21 Ridwan Khairandy, Op.Cit., h. 251-252.

22 John M. Echols Dan Hassan Shadily, Kamus Inggris Indonesia, An English-Indonesia Dictionary, Jakarta: Gramedia, 1995, h. 18.

23 Black's Law Dictionary, Op.Cit., h. 67-68.

24 H.M.N. Purwosutjipto, Op.Cit., h. 47. Periksa juga Suharnoko, Op.Cit., h. 41, yang menyebutkan bahwa dalam praktek kegiatan bisnis, keagenan biasanya diartikan sebagai hubungan hukum antara pihak prinsipal dengan agen, dimana pihak prinsipal memberi wewenang kepada agen untuk melakukan transaksi dengan pihak 
Lain halnya dengan Soekardono yang mengatakan bahwa ditinjau dari sudut pemberian perantaraan, agen keliling tidak berbeda dengan agen perniagaan yang juga menghubungkan pengusaha dengan pihak ketiga, tetapi pedagang keliling terikat dengan ikatan perburuhan dengan majikannya, sedangkan agen perniagaan sebagai perantara yang berdiri sendiri. Hal ini karena perjanjian yang mengikat agen bukan perjanjian perburuhan melainkan perjanjian untuk melakukan pekerjaan. ${ }^{25}$ Dalam ketentuan The Civil Code Netherlands in Article 7:428 disebutkan,

An agent must be an independent intermediary. There is no employee-employer relationship between him and his principal. The agent does not act in his own name, but in the name, to the expense and at the risk of his principal. There must be a steady relationship between principal and agent; incidental mediation is not enough to constitute an agency contract. ${ }^{26}$

Jadi agen merupakan individu atau suatu badan usaha independen yang mewakili perusahaan lainnya/prinsipal sebagai perantara dalam melakukan kegiatan bisnis, misalnya menjual suatu produk, untuk dan atas nama prinsipal kepada pihak ketiga dalam wilayah pemasaran tertentu, sehingga antara agen dan prinsipal mempunyai hubungan yang kuat. Dengan demikian, tugas agen perniagaan itu sebenarnya untuk memperluas pemasaran, hanya tidak berdasarkan hubungan kerja tetapi berdasarkan perjanjian keagenan ${ }^{27}$. Menurut Y. Sogar Simamora, agen bukanlah karyawan prinsipal, perbuatan mengadakan perjanjian dengan pihak ketiga merupakan kuasa prinsipal. Keagenan diartikan sebagai hubungan hukum dimana agen diberi kuasa bertindak atas nama prinsipal untuk melaksanakan transaksi bisnis dengan pihak lain. Prinsipal bertanggung jawab atas tindakan agen, sepanjang dalam batas-batas wewenangnya. ${ }^{28}$

Berkaitan dengan lembaga perantara yang diatur dalam WvK, agen dapat dianalogikan sebagai makelar apabila bertindak atas nama prinsipal dan sebagai komisioner apabila bertindak atas namanya sendiri, bertanggung jawab sendiri terhadap hubungan hukum yang dilakukan dengan pihak ketiga. Dengan demikian, maka para pihak yang terdapat dalam keagenan terdiri dari: 1) Prinsipal, adalah pihak yang memberi perintah/kuasa kepada agen untuk melakukan perbuatan hukum tertentu dalam hubungannya dengan pihak ketiga. Penunjukan agen oleh prinsipal dilakukan secara tertulis dalam bentuk kontraktual, termasuk hak dan kewajiban masing-masing; 2) Agen, adalah pihak penerima perintah/kuasa untuk melakukan perbuatan hukum tertentu dalam hubungannya dengan pihak ketiga yang tercantum dalam perjanjian, termasuk hak dan kewajiban masing-masing; 3) Pihak ketiga, adalah pihak yang melakukan

ketiga. Hubungan hukum antara prinsipal dengan agennya dapat berupa perwakilan, dimana agen bertindak untuk dan atas nama prinsipal. Periksa juga Richard Burton Simatupang, Aspek Hukum Dalam Bisnis (Edisi Revisi), Cetakan Kedua, Jakarta: Asdi Mahasatya, 2003, h. 53.

25 Soekardono, Hukum Dagang Indonesia, Jakarta: Dian Rakyat, 1993, h. 67.

26 Arthur S. Hartkamp and Marianne M.M. Tillema, Contract Law in the Netherlands, the Nertherlands: Kluwer Law International, 1995, h. 154.

27 Sentosa Sembiring, Hukum Dagang-Revisi, Bandung: Citra Aditya Bakti, 2008, h.120.

28 Y. Sogar Simamora, "Pemahaman Terhadap Beberapa Aspek Dalam Perjanjian", Yuridika, No.2, MaretApril 1996, h. 74. Periksa juga Richard Burton Simatupang, Op.Cit., h. 53 dan Suharnoko, Op.Cit., h. 41-42. 
perbuatan hukum atau transaksi dengan agen. Sehubungan hal tersebut, dalam keagenan terdapat beberapa karakteristik yang berbeda dengan perantara lainnya, yaitu: Agen menjual barang atau jasa atas nama prinsipal dalam transaksi dengan pihak ketiga; Prinsipal bertanggung jawab atas tindakan agen sepanjang sesuai kewenangannya;Agen menerima komisi dari hasil penjualan barang atau jasa kepada konsumen; Barang tetap milik prinsipal, dikirim langsung dari prinsipal ke konsumen tanpa melalui agen; Pembayaran langsung dari konsumen kepada prinsipal tanpa melalui agen. ${ }^{29}$

Sekalipun dalam praktek terdapat berbagai jenis agen, secara garis besar dapat diklasifikasikan menjadi dua jenis agen, yaitu agen umum (general agent) dan agen khusus (special agent). Semua agen dalam karakter apapun apabila bertindak untuk pekerjaaan dengan spesialisasi tertentu disebut agen khusus, sedangkan untuk pekerjaan tanpa spesialisasi tertentu disebut agen umum.

\section{Distributor}

Distributor tidak bertindak atas nama pihak yang menunjuknya sebagai distributor (biasanya supplier, atau manufacture), namun bertindak atas nama sendiri..$^{30}$ Pada dasarnya distributor adalah seorang pedagang yang membeli barang dari pabrikan atau manufacturer (sebagai prinsipal atau produsen) untuk dijual kembali oleh distributor atas nama diri sendiri. Perjanjian distribusi terjadi setelah prinsipal sebagai penjual menunjuk pembeli sebagai distributor. Setelah distributor mendapatkan barang dari prinsipal, wajib memasarkan dan menjual kepada konsumen wilayah yang ditentukan. Jadi perjanjian distribusi adalah perjanjian antara prinsipal dan distributor untuk memasarkan dan menjual produk yang dihasilkan prinsipal ke konsumen. Barang dipasarkan dan dijual oleh distributor setelah membeli dari prinsipal. Jadi secara yuridis barang yang dijual adalah barang milik distributor sendiri dan mendapat keuntungan dari margin atau selisih antara harga pembelian dan penjualan kepada konsumen.

Terdapat perbedaan esensial karakteristik antara agen dan distributor, yaitu: 1) Agen merupakan individu atau badan usaha yang menjual barang atau jasa atas nama prinsipal. Pendapatan yang diterimanya berupa komisi atas hasil penjualan barang atau jasa tersebut. Barang dikirim langsung dari prinsipal kepada konsumen dan pembayaran oleh konsumen langsung kepada prinsipal bukan melalui agen; 2) Distributor menjual barang atau jasa bertindak atas namanya sendiri sebagai independent trader. Membeli barang dari produsen atau supplier dan menjual kembali kepada konsumen untuk kepentingannya sendiri, pendapatannya berupa laba dari selisih jual beli tersebut. Barang dikirim dari prinsipal ke distributor kemudian dari distributor ke konsumen, sehingga prinsipal tidak berhubungan dan tidak mengetahui konsumennya. Distributor bertanggung jawab atas pembayaran barangnya dari pelanggan untuk kepentingan sendiri.

29 Munir Fuady, Pengantar Hukum Bisnis, Menata Bisnis Modern di Era Global, Bandung: Citra Aditya Bakti, 2002, h. 153.

30 Richard Burton Simatupang, Op.Cit., h. 53. 
Dalam sistem hukum Indonesia, baik dalam BW maupun WvK tidak mengatur secara khusus tentang keagenan, distributor dan dealer, akan tetapi didasarkan pada prinsip kebebasan berkontrak dalam Pasal 1338 ayat 1 BW, yaitu para pihak dapat membuat perjanjian apa saja termasuk perjanjian keagenan sepanjang tidak bertentangan dengan ketentuan undang-undang, ketertiban umum dan kesusilaan. Oleh karena itu, secara konseptual dasar hukum mengenai keagenan ini secara umum dapat merujuk pada: 1) BW tentang asas kebebasan berkontrak dan pemberian kuasa; 2) WvK tentang makelar dan komisioner; 3 ) Bidang-bidang hukum khusus, seperti dalam perundang-undangan di bidang pasar modal yang mengatur tentang dealer atau pialang saham; 4) Peraturan administratif, seperti peraturan dari Departemen Perdagangan atau Perindustrian yang mengatur masalah administrasi dan pengawasan terhadap masalah keagenan itu. ${ }^{31}$

\section{Karakteristik Keagenan Bank}

Bank termasuk jenis perantara di luar perusahaan karena mewakilli prinsipal melakukan transaksi perbankan seperti, pembayaran (payment), penerimaan dana dari pihak ketiga serta menyimpannya sesuai perintah prinsipal selaku nasabah bank dan transaksi lainnya. Hubungan hukum bank dengan prinsipal timbul berdasarkan perjanjian dan pemberian kuasa, tidak terikat perjanjian perburuhan melainkan perjanjian untuk melakukan pekerjaan sehingga kedudukannya sejajar, meskipun bertindak atas nama prinsipal. Prinsipal yang dimaksud dalam produk non bank ini adalah Manajer Investasi.

Dalam konsep keagenan bank, bank termasuk perantara yang diatur di luar WvK, sifatnya khusus dibandingkan keagenan pada umumnya. Dasar hukumnya merujuk pada BW meskipun tidak mengatur khusus tentang keagenan, namun berdasarkan prinsip kebebasan berkontrak dan pemberian kuasa untuk perjanjian kerjasamanya, juga berdasarkan UU Perbankan, ketentuan BI, Bapepam-LK serta OJK berkaitan dengan regulasi keagenan bank dan pengawasan perbankan yang tunduk dalam pengawasan OJK. Jadi dalam pelaksanaannya, bank diberi kuasa bertindak atas nama Manajer Investasi untuk melaksanakan transaksi produk non bank dengan nasabah. Manajer Investasi bertanggung jawab atas tindakan bank sepanjang dalam batas-batas kewenangan dalam perjanjian, namun apabila bank bertindak melampaui batas-batas kewenangannya, risiko menjadi tanggung jawab bank.

Para pihak yang terlibat dalam keagenan bank, seperti keagenan pada umumnya juga terdiri dari tiga pihak, yaitu: 1) Manajer Investasi sebagai prinsipal memberi kuasa pada bank sebagai agen untuk memproses dan melaksanakan transaksi produk non bank dengan nasabah. Penunjukan bank sebagai agen oleh prinsipal berdasarkan perjanjian kerjasama dalam bentuk kontraktual yang juga memuat hak dan kewajiban para pihak; 2) Bank sebagai agen, melaksanakan kuasa prinsipal untuk melakukan transaksi dengan nasabah; 3) Nasabah sebagai pihak ketiga yang melakukan transaksi dengan bank. Berkaitan dengan jenis agen yang secara garis besar ada dua jenis, yaitu agen umum (general agent) dan agen khusus (special agent),

31 Munir Fuady, Op.Cit., h. 246. 
maka bank termasuk katagori agen khusus karena melakukan pekerjaaan khusus seperti yang tercantum dalam perjanjian kerjasama, yaitu khusus melakukan pemasaran dan penjualan produk non bank milik prinsipal beserta hal-hal terkait lainnya. Dengan demikian, bank tidak boleh melakukan tindakan lain yang tidak sesuai dengan perjanjian kerjasama karena segala risiko menjadi tanggung jawab bank.

Apabila dikaitkan dengan lembaga perantara yang terdapat dalam WvK, dalam hal ini makelar dan komisioner, keagenan bank ini mempunyai persamaan terhadap keduanya, yaitu: 1) Sebagai perantara bisnis antara prinsipal dengan nasabah;2) Menerima komisi dari prinsipal berdasarkan perjanjian; 3) Terikat perjanjian dengan prinsipal; 4) Persamaan dengan makelar, yaitu tidak punya hubungan tetap dengan prinsipal, bertindak atas nama prinsipal berdasarkan perjanjian. Identitas prinsipal diungkapkan dan diketahui nasabah serta prinsipal memiliki hak tagih ke nasabah dan nasabah dapat menuntut prinsipal. Perbedaan dengan keduanya adalah bahwa keagenan bank diatur dalam BW tentang prinsip kebebasan berkontrak dan pemberian kuasa serta UU Perbankan, ketentuan BI, Bapepam - LK dan OJK dan hanya bertindak sebagai perusahaan karena bank merupakan badan usaha.

Dari penjelasan tersebut, bank sebagai agen produk non bank identik dengan makelar karena bertindak atas nama prinsipal dan tidak identik dengan komisioner karena tidak bertindak atas namanya sendiri. Berdasarkan sifat khusus keagenan bank, pelaksanaannya tunduk pada UU Perbankan, ketentuan BI, Bapepam-LK dan OJK.

\section{Kesimpulan}

Dari penjelasan diatas, maka karakteristik bank sebagai agen penjual produk non bank mempunyai karakteristik khusus dibandingkan agen pada umumnya. Bank termasuk jenis perantara di luar perusahaan, hubungan hukumnya dengan Manajer Investasi berdasarkan perjanjian kerjasama dan pemberian kuasa, mempunyai kedudukan yang sejajar dengan Manajer Investasi. Dasar hukumnya diatur di luar WvK dan merujuk pada BW berdasarkan prinsip kebebasan berkontrak dan pemberian kuasa, UU Perbankan serta ketentuan BI, BapepamLK dan OJK. Pengawasan bank dilakukan oleh OJK sebagai otoritas yang berwenang yang ditentukan oleh Undang-Undang.

Bank termasuk katagori agen khusus karena hanya melakukan pekerjaaan khusus sesuai yang tercantum dalam perjanjian kerjasama. Kedudukan bank sebagai agen identik dengan makelar karena bertindak untuk dan atas nama Manajer Investasi, dan Manajer Investasi bertanggung jawab atas tindakan bank sepanjang sesuai kewenangannya. Pendapatan yang diterima bank berupa komisi sebagai fee based income dari hasil penjualan produk. Bukti pembelian produk dikirim Manajer Investasi ke nasabah tanpa melalui bank. Pembayaran atas pembelian produk dapat dilakukan langsung oleh nasabah pada Manajer Investasi tanpa melalui bank, namun dalam prakteknya bank membantu proses pembayaran tersebut melalui mekanisme transfer. 


\section{Daftar Bacaan}

\section{Buku}

Echols, John M. Dan Hassan Shadily, Kamus Inggris Indonesia, An English-Indonesia Dictionary, Cetakan Kedua Belas, Jakarta: Gramedia, 1995.

Fuady, Munir, Pengantar Hukum Bisnis, Menata Bisnis Modern di Era Global, Bandung: Citra Aditya Bakti, 2002.

Garner, Bryan A., Black’s Law Dictionary, Eighth Edition, West Publishing Co, U.S., 2004.

Hartkamp, Arthur S. and Marianne M.M. Tillema, Contract Law in the Netherlands, Nertherlands: Kluwer Law International, 1995.

Heffernan, Shelagh, Modern Banking in Theory and Practice, England: John Wiley \& Sons, 1996.

Kansil, C.S.T. dan Christine S.T. Kansil, Pokok-Pokok Pengetahuan Hukum Dagang Indonesia, Cetakan Keempat, Jakarta: Sinar Grafika, 2008.

Khairandy, Ridwan, Pokok-Pokok Hukum Dagang Indonesia, Cetakan Pertama, Yogyakarta: FH UII Press, 2013.

Purwosutjipto, H.M.N., Pengertian Pokok Hukum Dagang Indonesia (Pengetahuan Dasar Hukum Dagang), Cetakan kelima, Jakarta: Djambatan, 1985.

Rae, Dian Ediana, Transaksi Derivatif dan Masalah Regulasi Ekonomi di Indonesia, Jakarta: Elex Media Kompotindo, 2008.

Sembiring, Sentosa, Hukum Dagang-Revisi, Bandung: Citra Aditya Bakti, 2008.

Simatupang, Richard Burton, Aspek Hukum Dalam Bisnis (Edisi Revisi), Cetakan Kedua, Jakarta: Asdi Mahasatya, 2003.

Soekardono, Hukum Dagang Indonesia, Jakarta: Dian Rakyat, 1993.

Suharnoko, Hukum Perjanjian Teori dan Analisa Kasus, Cetakan ketujuh, Jakarta: Kencana Prenada Media, 2012.

Widiyono, Try, Aspek Hukum Operasional Transaksi Produk Perbankan di Indonesia, Cetakan Pertama, Bogor: Ghalia Indonesia, 2006.

Widoatmodjo, Sawidji, Cara Sehat Investasi di Pasar Modal, Pengantar Menjadi Investor Profesional, Jakarta: Elex Media Komputindo, 2006.

\section{Makalah}

Putera, Andika Persada, "Fee Based Income sebagai Alternatif Pendapatan Bank”, Surabaya Post, 12 Januari 2006.

Simamora, Y. Sogar, "Pemahaman Terhadap Beberapa Aspek Dalam Perjanjian", Yuridika, 
No.2, Maret-April 1996.

Sitompul, Zurkarnain, “Menyambut Kehadiran Otoritas Jasa Keuangan (OJK)”, Pilars No.02/ Th.VII/12, 8 Januari 2004.

\section{Peraturan Perundang-Undangan}

Undang-Undang Republik Indonesia Nomor 7 Tahun 1992 tentang Perbankan. Lembaran Negara Republik Indonesia Tahun 1992 Nomor 31. Tambahan Lembaran Negara Republik Indonesia Nomor 3472.

Undang-Undang Republik Indonesia Nomor 10 Tahun 1998 tentang Perubahan Undang-Undang Nomor 7 Tahun 1992 Tentang Perbankan. Lembaran Negara Republik Indonesia Tahun 1998 Nomor 182. Tambahan Lembaran Negara Republik Indonesia Nomor 3790.

Peraturan Bank Indonesia Nomor 7/6/PBI/2005 tanggal 20 Januari 2005, tentang Transparansi Informasi Produk Bank Dan Penggunaan Data Pribadi Nasabah.

Keputusan Ketua Badan Pengawas Pasar Modal Dan Lembaga Keuangan Nomor KEP-10/ BL/2006 tanggal 30 Agustus 2006, tentang Pendaftaran Agen Penjual Efek Reksa Dana.

Keputusan Ketua Badan Pengawas Pasar Modal Dan Lembaga Keuangan Nomor KEP-11/ BL/2006 tanggal 30 Agustus 2006, tentang Perilaku Agen Penjual Efek Reksa Dana.

Surat Edaran Bank Indonesia Nomor 5/13DPG/DPNP tanggal 3 Oktober 2003, perihal Prinsip Kehati-hatian Bagi Bank dalam Melakukan Kegiatan Yang Terkait Dengan Reksa Dana.

Surat Edaran Bank Indonesia Nomor 7/19/DPNP tanggal 14 Juni 2005, perihal Penerapan Manajemen Risiko pada Bank yang Melakukan Aktivitas Berkaitan Aktivitas Reksa Dana oleh Bank.

Surat Edaran Bank Indonesia Nomor 7/25/DPNP tanggal 18 Juli 2005, perihal Transparansi Informasi Produk Bank dan Penggunaan Data Pribadi Nasabah.

Surat Edaran Bank Indonesia Nomor 11/35/DPNP tanggal 31 Desember 2009, perihal Pelaporan Produk atau Aktivitas Baru.

Surat Edaran Bank Indonesia Nomor 11/36/DPNP tanggal 31 Desember 2009, perihal Perubahan atas Surat Edaran Bank Indonesia Nomor 7/19/DPNP tanggal 14 Juni 2005 perihal Penerapan Manajemen Risiko pada Bank yang Melakukan Aktivitas Berkaitan dengan Reksa Dana.

\section{Laman}

Sindonews.com,http://ekbis.sindonews.com/read/2014/01/07/32/824281/dana-kelolaan-reksadana-2013-naik-tipis, diakses pada tanggal 28 Maret 2013.

http://aria.bapepam.go.id, diakses pada tanggal 21 April 2013. 